Sánchez-Rodríguez, Cristóbal \& Martínez-Lorente, Angel. (2011). Effect of IT and Quality Management on Performance.. Industrial Management and Data Systems. 111. 10.1108/02635571111144937.

\title{
Effect of IT and Quality Management on Performance
}

\section{Introduction}

Quality has been typically regarded as a key strategic component of competitive advantage and the enhancement of product quality is still a matter of prime concern for today's firms (Soltani et al., 2011; Li et al., 2011). Moreover, a frequent concern is that product quality no longer provides enduring competitive advantage but instead it may have become primarily a competitive prerequisite (Dunk, 2002). Hence the assessment of how IT can lead to improvements in quality performance is likely to be of considerable interest to both practitioners and academics.

The IT-performance relationship has received considerable attention in the IT literature and there is a common agreement that the adoption of a particular technology often does not provide a sustained competitive advantage for the adopting firms because it can be easily duplicated by other firms (Powell and Dent-Micalef, 1997). Consequently, the IT literature has suggested the need to identify contingencies that may govern the IT- performance relationship (Das et al., 2000; Cagliano and Spina, 2000) and to uncover which factors are synergistic with which types of IT and in what contexts (Melville et al., 2004).

Given that much of the attention that IT has received in the operations literature today is due to the diffusion of the total quality management principles (TQM) (Gunasekaran and Ngai, 2004) and that quality management is also one of the most important management philosophies directed towards improving quality performance, this paper will focus on the mediating role of quality management in the relationship between IT and quality performance.

For the purposes of this study, quality management is defined as a "set of mutually reinforcing principles, each of which is supported by a set of practices and techniques" (Dean and Bowen, 1994). Arguments for the relationship between information technology (IT) and 
quality management can be found in the resource based view of the firm (Peteraf, 1993; Barney, 1991; Barney, 1986), and the notion of resource complementarity. Complementarity represents an enhancement of resource value, and arises when a resource produces greater returns in the presence of another resource than it does alone. Thus, we argue that IT and quality management are complementary resources and that makes IT have a positive effect on quality performance.

Consequently, this paper will try to answer the following research questions: are IT and quality management complementary resources? In other words, does quality management play a significant role in the relationship between IT and quality performance? In order to respond to these questions we hypothesize a research model linking IT, quality management and quality performance. The research model is then tested using structural equations modelling and survey data from 229 manufacturing firms in Spain.

The rest of this article is organized as follows: we begin with review of the resourcebased view related to IT and quality management then, a framework that links IT to quality management and quality performance is presented. This is followed by a discussion of the survey methodology, empirical findings, managerial implications, and limitations.

\section{Literature review and theoretical background}

Previous literature has devoted valuable interest to the relationship between IT and quality management studying such issues as how specific IT applications impact various aspects of quality management (Kock and McQueen, 1997), the role of IT in a quality management system (Dewhurst et al., 2003; Forza, 1995); and the development of measurement instruments to assess the level of IT use to support quality management (Ang et al., 2001; Martinez-Lorente et al., 2004; Sánchez-Rodríguez et al., 2006). However, some authors have suggested that technology as an external driver of TQM still needs more studies (McAdam and Henderson, 2004).

Arguments for the value of information technology (IT) to support quality management capabilities find a basis in the resource-based view of the firm (Peteraf, 1993; Barney, 1991; 
Barney, 1986), which argues that, to confer competitive advantage, an organization should acquire or develop resources and/or capabilities that contribute positively to performance, are not possessed by all competing firms, and are difficult to imitate or duplicate (Barney, 1986). These resources and capabilities can either be acquired in factor markets and/or developed inside the firm.

Information technology, as part of a firm's resource portfolio, may not meet the resourcebased view criteria when acting alone. Due to the relatively low barriers to imitation and acquisition by other firms, an IT-based advantage tends to diminish fairly quickly. In contrast, the resource-based view has emphasized sustainability protected by resource embeddedness, i.e., resource complementarity and co-specialization (Powell and Dent-Micalef, 1997). As mentioned earlier, complementarity represents an enhancement of resource value, and arises when a resource produces greater returns in the presence of another resource than it does alone.

Based on this definition of resource complementarity, one could argue that quality management and IT are complementary resources. Previous research supports this view. For example, Schniederjans and Kim (2003) concluded that firms implementing both ERP and TQM would achieve predominant success. Laframboise and Reyes (2005) found that ERP implementation positively affects a firm's performance when the enterprise information system implementation directly interacts with quality improvement systems. Mjema et al. (2005) showed that the introduction of IT on quality management has contributed greatly to the enhancement of quality awareness in the improvement of product quality and in the reduction of quality costs. And Brah and Lim (2006) found that TQM and technology play important and complementing roles in improving performance. Their analysis showed that both high technology firms and high technology TQM firms perform significantly better than their low technology peers.

Therefore, we propose that through embedding IT in a firm’s quality management efforts, IT can facilitate the development of higher-order organizational capabilities, which are firm specific and hard to duplicate across organizations. As such, the relationship between information technology and performance would be indirect and mediated by quality management 
as it is portrayed in the research model by the absence of any direct link between information technology and quality performance (see Figure 1). The proposed research model is described next.

$<$ Take in Figure 1>

\section{Research model and hypotheses}

Quality management has been defined in the literature as a "set of mutually reinforcing principles, each of which is supported by a set of practices and techniques” (Dean and Bowen, 1994) and comprising a set of key dimensions (Flynn et al., 1994; Saraph et al., 1989) (see Table 1). One could argue that the combination of these dimensions according to the nature could give rise to a set of quality management capabilities. Quality management capabilities refer to the ability of an organization to identify, utilize, and assimilate both internal and external resources/information to facilitate the completion of quality management activities in order to develop products and services that satisfy or exceed customer expectations. As such, we could identify three distinct quality management capabilities: Customer and Supplier Relations, Quality Data and Workforce Management, and Product and Process Management.

These three quality management capabilities represent all the important activities involved in quality management and consistent with previous literature (Jung et al., 2009). Each of the three dimensions reflects an ability to perform cross-functional as well as interorganizational activities which are required in quality management. Customer Supplier Relations deals with collaborative relations with external stakeholders (customers and suppliers). Quality Data and Workforce Management main focus is on people and entails the collection and analysis of quality data for decision making and the empowerment of employees through teamwork, training, and recognition. Product and Process Management deals with the design and manufacturing of reliable products that meet and exceed the needs of customers.

In the present study we define IT in terms of adoption and use and for the purposes of this study we identified three information technologies that were complementary to the identified quality management capabilities; electronic data interchange (EDI) has been a common technology used in managing the information flow with customer and suppliers and still is one of 
the most widely used technologies among trading partners (Johnson et al., 2007). Computeraided design (CAD) and computer-aided manufacturing (CAM) are widely used technologies in product design and manufacturing therefore one of the most appropriate technologies to understand the relationship between IT and product and process management. Enterprise resource planning systems (ERP) was also chosen because of its ability to manage multiple areas of a firm including sales and procurement, process design, production planning and scheduling, inventory management, quality control and human resource management (Gupta and Kohli, 2006), thus, making it an appropriate IT tool to analyze the relationship between IT and quality data and workforce management.

Table 1. Quality management key dimensions

\begin{tabular}{|c|c|}
\hline TQM dimensions & Description \\
\hline $\begin{array}{l}\text { Customer } \\
\text { relationships }\end{array}$ & $\begin{array}{l}\text { The needs of customers and consumers and their satisfaction have always to } \\
\text { be in the mind of all employees. It is necessary to identify these needs and } \\
\text { their level of satisfaction. }\end{array}$ \\
\hline $\begin{array}{l}\text { Supplier } \\
\text { relationships }\end{array}$ & $\begin{array}{l}\text { Quality is a more important factor than price in selecting suppliers. Long- } \\
\text { term relationship with suppliers has to be established and the company has } \\
\text { to collaborate with suppliers to help improve the quality of } \\
\text { products/services. }\end{array}$ \\
\hline $\begin{array}{l}\text { Workforce } \\
\text { management }\end{array}$ & $\begin{array}{l}\text { Workforce management has to be guided by the principles of: training, } \\
\text { empowerment of workers and teamwork. Adequate plans of personnel } \\
\text { recruitment and training have to be implemented and workers need the } \\
\text { necessary skills to participate in the improvement process. }\end{array}$ \\
\hline $\begin{array}{l}\text { Product } \\
\text { process }\end{array}$ & $\begin{array}{l}\text { All departments have to participate in the design process and work together } \\
\text { to achieve a design that satisfies the requirements of the customer, } \\
\text { according to the technical, technological and cost constraints of the } \\
\text { company. }\end{array}$ \\
\hline $\begin{array}{l}\text { Process } \\
\text { management }\end{array}$ & $\begin{array}{l}\text { Statistical and non-statistical improvement instruments should be applied as } \\
\text { appropriate. Processes need to be mistake proof. Self-inspection undertaken } \\
\text { using clear work instructions. The process has to be maintained under } \\
\text { statistical control. }\end{array}$ \\
\hline $\begin{array}{l}\text { Quality data } \\
\text { and reporting }\end{array}$ & $\begin{array}{l}\text { Quality information has to be readily available and the information should } \\
\text { be part of the visible management system. Records about quality indicators } \\
\text { have to be kept, including scrap, rework and cost of quality. }\end{array}$ \\
\hline
\end{tabular}


Similar to quality management, quality performance has been reflected and measured in various ways in past empirical studies. However, product quality is often used to measure quality performance because it is often considered to contribute to the development of competitive advantage (Ahire et al., 1996; Dow et al., 1999). Thus, we define quality performance in terms of product quality.

\subsection{EDI, CAD/CAM and ERP}

One of the major shortcomings of manufacturing information systems has been their inability to integrate and to enhance different information and related functionalities (Montaldo et al., 2003). In response to this situation, firms are adopting ERP systems to be integrated with other company systems. For example, EDI systems tend to be one of the most common systems to be integrated with ERP systems (Themistocleous et al., 2001). Also, organizations are integrating their CAD and CAM systems with new ERP implementations in order to maintain or gain a competitive advantage (Soliman et al., 2001). This leads us to propose the following hypotheses:

H1: The use of EDI is directly and positively associated with ERP.

H2: The use of CAD/CAM systems is directly and positively associated with ERP

\subsection{IT and Quality Data and Workforce Management}

Quality management requires the feedback of quality performance indicators for the purpose of continuous improvement. Therefore, appropriate performance data must not only be collected but also communicated which can be facilitated by the use of IT systems (Chang, 2006). Since communication is inherent to quality management, this climate of open, two-way communication has pervasive associated benefits, affecting the attitude to organizational life for all employees, and promoting employee empowerment, teamwork, motivation, training and general industrial relations (Cua et al., 2001; Fok et al., 2001). As such we would expect all three IT (EDI, ERP and CAD/CAM) to contribute to Quality Data and Workforce Management capabilities by collecting and communicating quality performance and employee empowerment. This discussion leads us to the following hypotheses: 
Hypothesis 3. EDI is directly and positively associated with Quality Data and Workforce Management.

Hypothesis 4: ERP is directly and positively associated with Quality Data and Workforce Management.

Hypothesis 5. CAD/CAM is directly and positively associated with Quality Data and Workforce Management.

\subsection{IT and Customer and Supplier Relations}

The literature contains early evidence supporting the resource complementarity between EDI and quality management capabilities (Sandelands, 1994). More recently, supply managers have also reported that the integration between quality management and ERP systems is also essential for managing customers and supplier relationships (Foster and Ogden, 2008) allowing a firm to integrate major supply chain processes, plan production, logistics and marketing promotions (Overby and Min, 2001). Therefore, we propose the following hypotheses:

Hypothesis 6. EDI is directly and positively associated with Customer and Supplier Relations.

Hypothesis 7: ERP is directly and positively associated with Customer and Supplier Relations.

\subsection{IT and Product and Process Management}

ERP systems such as SAP R/3 system include functionality to specifically support operations activities such as process design, production planning and scheduling, inventory management and quality control among other (Gupta and Kohli, 2006). The literature is also supportive of ERP and Product and Process Management as complementary resources. For example, early survey studies on TQM found evidence of firms implementing CAD and CAM technologies along with total quality management (Czajkiewicz and Wielicki, 1994). Jiang and Chiu (2002) demonstrated how CAD and CAM technologies can be used for statistical process control purposes. Madu (2005) also developed a company-wide reliability information system and suggested that it should be integrated within an ERP to manage design and manufacturing quality management tools such as statistical process control, Pareto charts, and failure mode and effect analysis (FMEA). This discussion leads us to propose the following hypotheses: 
Hypothesis 8: ERP is directly and positively associated with Product and Process Management.

Hypothesis 9. CAD/CAM is directly and positively associated with Product and Process Management.

\subsection{Quality management capabilities}

Recent evidence from the quality management literature suggests that Data Quality and Workforce Management capabilities are necessary to develop successful relationships with customers (Sila and Ebrahimpour, 2005; Kaynak and Hartley, 2008) and suppliers (Sila and Ebrahimpour, 2005; Kaynak and Hartley, 2008). Similarly, the collection and analysis of quality data and workforce management have been suggested as antecedents of effective product design (Sila and Ebrahimpour, 2005; Kaynak and Hartley, 2008) and process control activities (Sila and Ebrahimpour, 2005; Kaynak and Hartley, 2008). Therefore, the following hypotheses were formulated:

Hypothesis 10. Quality Data and Workforce Management is directly and positively associated with Customer and Supplier Relations.

Hypothesis 11. Quality Data and Workforce Management is directly and positively associated with Product and Process Management.

The literature also suggests that close collaborative relationships with suppliers facilitates their involvement in the company’s new product design (Kaynak and Hartley, 2008) and process control activities (Kaynak and Hartley, 2008). Similarly, the involvement of customers in new product development would be facilitated by closer collaborative relationships with customers (Flynn et al., 1994). Therefore, we propose the following hypothesis:

Hypothesis 12. Customer and Supplier Relations is directly and positively associated with Product and Process Management.

\subsection{Quality management capabilities and quality performance.}

The design and manufacture of products tailored to meet customer requirements should enhance quality performance (Flynn et al., 1994). Recent evidence in the literature has found that only product design and process control have a direct effect on quality performance (Kaynak and 
Hartley, 2008). On the other hand, employee relations, training, and quality data and reporting, customer focus, and supplier quality management did not have a direct impact on quality performance but the effect was mediated by product design and process control (Kaynak and Hartley, 2008). Therefore we propose the following hypothesis:

Hypothesis 13. Product and Process Management is directly and positively associated with Quality Performance

\section{Research methodology}

We tested the foregoing hypotheses using data surveyed from manufacturing firms implementing quality management. In the following sections we describe the sample and data collection procedures and the validation of measures.

\subsection{Sample and data collection}

The study utilized a cross-sectional mail survey of a sample of Spanish manufacturing companies drawn from "Fomento de la Produccion” company directory. 1949 respondents were selected from a list of the 3000 largest manufacturing firms. The title of the specific respondent sought was primarily Quality Manager or Quality Director. The questionnaire was developed in Spanish and was pretested with quality managers from a sample of 14 large Spanish manufacturers.

In an effort to increase the response rate, a modified version of Dillman's (1978) total design method was followed. Survey questionnaires were sent to respondents via first-class mail during the month of October 2001; each survey included a cover letter and postage-paid return envelope. Two weeks after the initial mailing, reminder postcards were sent to all potential respondents. For those who did not respond a second wave of surveys, cover letters, and postagepaid return envelopes were mailed approximately 6 weeks after the initial mailing. A cover letter was sent with the questionnaire presenting the objective of the research and provided respondents with the definitions of the quality management dimensions included in Table I.

The resulting sample included 442 firms which resulted in an initial response rate of 22.7\% and was comparable to similar studies in the literature (Frohlich and Dixon, 2001). Of 
those 442 respondents, $52.9 \%$ of companies $(n=234)$ identified themselves as having adopted a quality management program. Of the 234 cases, fifteen had incomplete data for the purposes of the data analysis, resulting in a final sample in 229 complete responses yielding a definitive $11.7 \%$ response rate.

In order to assess the validity of the self identification of firms as having adopted quality management, companies were asked to report which quality assurance program they had implemented. ISO-registered organizations would be expected to implement effective TQM practices compared with non-ISO-registered organizations as a result of their orientation towards ISO 9000 (Sila, 2007). As it can be seen in Table 2 almost all firms had implemented at least one quality assurance program among the ISO 9001, ISO 9002 and ISO 14001. This is a good indication that almost all the companies in the sample had a functioning quality management program adding validity to the sample responses.

To test for non-response bias, we compared the responses of early and late waves of returned surveys based on the assumption that the opinions of late respondents are representative of the opinions of non-respondents. We performed $t$-tests comparing early and late respondents on key demographic variables, namely number of employees and sales volume. We found no significant differences between early and late respondents. This suggests that nonresponse would not likely bias the findings. We used Harman's one-factor test to address the issue of common method variance. We performed factor analysis on items related to the predictor variables and no general factor was apparent in the unrotated factor structure. Therefore, no common method variance problem was detected.

Table 2. Firms with quality assurance programs

\begin{tabular}{lll}
\hline & Number of firms & Percentage \\
\hline Firms with a quality assurance program (ISO 9001, 9002, & 214 & $93.5 \%$ \\
14001, or other)* & 15 & 6.5 \\
No quality assurance program & 229 & $100 \%$ \\
Total & 15 \\
\hline
\end{tabular}


*Note: ISO 9001: 110 firms; ISO 9002: 104 firms; ISO 14001: 79 firms; Other: 54 firms.

Most respondents are from the consumer goods manufacturing industry, original equipment manufacturing and parts and components (see Table 3). Product quality is of key importance for all these three industries granting additional validity to the sample responses. Key informants in the sample consisted of quality managers (70.5\%), quality department representatives (10.5\%) and plant directors (3.4\%). Some $60 \%$ of the companies in the sample were made up of Spanish-owned firms, 21\% of other European Union (EU) countries, and 19\% from non-EU countries.

Table 3. Industry sectors

\begin{tabular}{llll}
\hline Manufacturing Industry & Number & Percentage & $\begin{array}{l}\text { Cumulative } \\
\text { percentage }\end{array}$ \\
\hline Consumer products & 67 & 29.2 & 29.2 \\
Original equipment & & 24.7 & 53.9 \\
manufacturer & 57 & 22.8 & 76.7 \\
Parts and components & 52 & 12.3 & 89.0 \\
Raw materials & 28 & 9.1 & 98.2 \\
Capital equipment & 21 & 1.8 & 100.0 \\
Energy & 4 & 100.0 & \\
\hline Total & 229 & & \\
\hline
\end{tabular}

\subsection{Construct measurement}

EDI, ERP and CAD/CAM were measured by using a five-point scale ( $1=$ no use, $5=$ intensive use) similar to other studies in the literature (Johnson et al., 2007). Quality management was also measured using a five-point scale (1 represented "no use" and 5 represented "intensive use") and asking respondents about the use of quality management in customer relations, supplier relations, employee relations, data quality and reporting, product design, and process management (Gutiérrez and Pérez, 2010).

Quality performance was measured in terms of defect rate at final assembly (Fynes and De Burca, 2005), a firm's product quality relative to its competition (Lo et al., 2007), and overall plant quality. Respondents were asked to report the comparative position of their firm with 
respect to competitors using a five-point scale, where 1 represented "not competitive at all” and 5 represented "very competitive.” Table 4 shows the descriptive statistics for all the indicators in the study.

\section{Analytical procedures}

The hypotheses were tested using Structural Equation Modelling (SEM). Structural equation modeling (SEM) is a statistical technique that combines elements of both multiple regression and factor analysis. SEM is often used to specify the phenomenon under study in terms of linkage between constructs and their indicators, and provides the researcher with a straightforward method of dealing with multiple relationships simultaneously while providing statistical efficiency. Thus if the model is correct, we will not reject the hypothesis that the model and observed covariance matrices are equal. A conceptual difference of SEM from regression analysis is that in a regression model the independent variables are themselves correlated (multico linearity) but in SEM the interactions amongst these variables are modeled, thus providing a more accurate coefficients (Dion, 2008).

Table 4. Descriptive statistics and measurement model results.

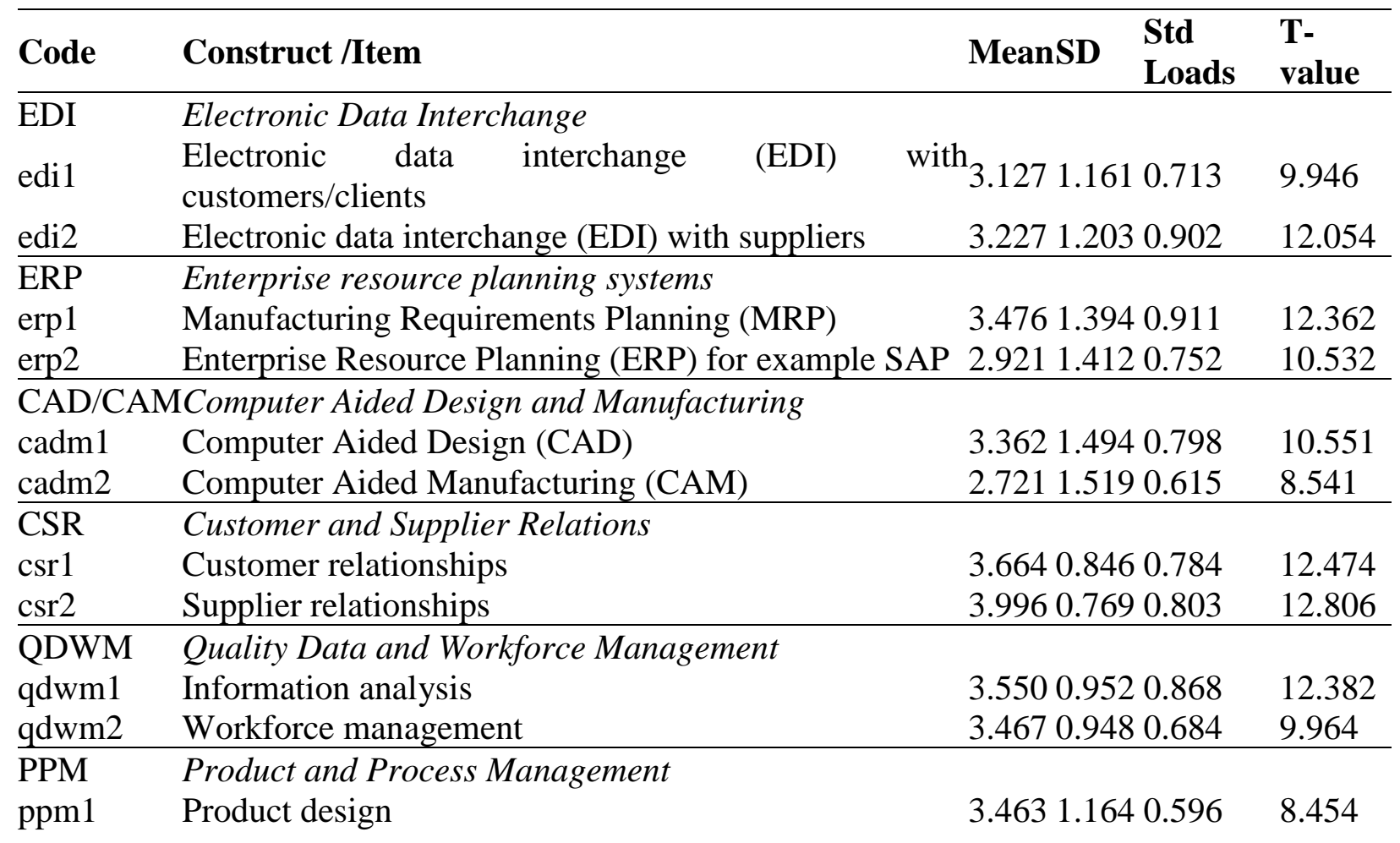




\begin{tabular}{llrl} 
ppm2 & Process flow management & 3.9300 .8190 .712 & 9.860 \\
\hline QP & Quality Performance & 3.8910 .8230 .796 & 11.196 \\
qp1 & Defective rates & 3.8860 .6720 .575 & 8.143 \\
qp2 & Product quality & $1.6550 .907-0.666$ & -9.452 \\
\hline qp3 & $\begin{array}{l}\text { Plant quality performance in the last 3 years (reverse } \\
\text { coded) }\end{array}$ & \\
\hline
\end{tabular}

In estimating a structural equations model it is important to determine the minimum sample size required in order to achieve a desired level of statistical power with a given model prior to data collection (McQuitty, 2004). Although there is no single recommended sample size for SEM, several authors have suggested a sample size above 200 provides sufficient statistical power for data analysis (Garver and Mentzer, 1999).

\subsection{Measurement model validation}

The analysis was carried out with LISREL 8.5 using the maximum-likelihood estimation method. The assumptions of multivariate analysis - normality, linearity, and homoscedasticity were tested for the variables used in the measurement model and the data showed high kurtosis statistics; thus, normal scores of variables were calculated using PRELIS and these scores were used in the analyses (Jöreskog et al., 2000).

A Confirmatory Factor Analysis (CFA) was undertaken to address the validity and reliability of the measurement model. Table 4 shows the factor loadings and $t$-values from the measurement model estimation. Multiple fit criteria were employed to evaluate the measurement model (Hair et al., 1995) and as it can be seen in Table 5, fit indices indicated an acceptable fit of the measurement model to the data.

Table 5. Test results of the measurement models and structural model

\begin{tabular}{llll}
\hline & $\begin{array}{l}\text { Measurement } \\
\text { Model }\end{array}$ & Structural Model & $\begin{array}{l}\text { Recommended } \\
\text { values }\end{array}$ \\
\hline Degrees of freedom & 69 & 76 & - \\
Chi-Square & 89.75 & 115.66 & - \\
p- value & 0.049 & 0.002 & $>0.05$ \\
$\chi^{2} /$ DF & 1.300 & 1.522 & $<3^{* *}$ \\
RMSEA & 0.036 & 0.048 & $0.05^{* *}$ \\
NFI & 0.921 & 0.901 & 0.90
\end{tabular}




\begin{tabular}{llll} 
NNFI & 0.970 & 0.957 & 0.90 \\
CFI & 0.980 & 0.965 & $0.95^{* *}$ \\
RMR & 0.044 & 0.054 & $0.10^{*}$ \\
GFI & 0.950 & 0.937 & $0.80^{*}$ \\
AGFI & 0.913 & 0.900 & $0.80^{*}$ \\
\hline
\end{tabular}

Notes: *(Chau, 1997), and **(Byrne, 2001)

Convergent validity addresses whether a set of alternative measures accurately represents the construct of interest and was assessed by reviewing the level of significance for the factor loadings (see Table 1). As can be seen from Table 1 the coefficients for all indicators were large and significant ( $t$-values $>1.96 ; \mathrm{p}<0.05$ two tail).

Scale reliability provides a measure of the internal homogeneity of the items comprising a scale and was calculated, as in (Hair et al., 1995), by:

$$
\frac{\left(\sum \text { factor loading }\right)^{2}}{\left(\sum \text { factor loading }\right)^{2}+\left(\sum \text { error variances }\right)}
$$

The values for composite reliabilities of all scales exceed the threshold value of equal to or greater than 0.60 (Bagozzi and Yi, 1988) (see Table 3).

Discriminant validity among the latent variables and their associated measurement variables can be assessed by fixing (i.e. constraining) the correlation between pairs of constructs to 1.0, re-estimating the modified model, and measuring the change in the chi-square statistic. The condition of discriminant validity is met if the difference of the chi-square statistics between the constrained and standard models is significant (1 degree of freedom.) The chi-square difference tests indicated that discriminant validity exists among all the constructs $(\mathrm{p}<0.05$.) Table 6 also reports correlations between the three information technology resources, quality management capabilities, and quality performance.

\begin{tabular}{|c|c|c|c|c|c|c|c|}
\hline & EDI & ERP & CADM & QDWM & CSR & PPM & QP \\
\hline EDI & $\begin{array}{l}0.79^{\mathrm{a}} ; \\
0.66^{\mathrm{b}}\end{array}$ & & & & & & \\
\hline ERP & $0.249^{\mathrm{C} * *}$ & $0.82 ; 0.70$ & & & & & \\
\hline CAD/CAM & $0.500^{* *}$ & $0.471^{* *}$ & $0.67 ; 0.51$ & & & & \\
\hline
\end{tabular}

Table 6. Reliability, variance explained and correlations 


\begin{tabular}{llllllll} 
QDWM & $0.294^{* *}$ & $0.324^{* *}$ & $0.258^{* *}$ & $0.76 ; 0.61$ & & & \\
CSR & $0.385^{* *}$ & $0.316^{* *}$ & 0.117 & $0.627^{* *}$ & $0.77 ; 0.63$ & & \\
PPM & $0.275^{* *}$ & $0.450^{* *}$ & $0.454^{* *}$ & $0.579^{* *}$ & $0.737^{* *}$ & $0.60 ; 0.43$ & \\
QP & 0.081 & 0.064 & -0.053 & $0.368^{* *}$ & $0.376^{* *}$ & $0.438^{* *}$ & $0.72 ; 0.47$ \\
\hline
\end{tabular}

Notes: values on the diagonal are $\left({ }^{\mathrm{a}}\right)$ composite reliabilities and $\left({ }^{\mathrm{b}}\right)$ explained variances; $\left({ }^{\mathrm{c}}\right)$ correlations; ${ }^{* *} p<0.01$; (two-tailed); $\mathrm{n}=229$

\subsection{Structural model}

For greater clarity, Figure 2 only includes the values of the structural equations, not the measurement model. The overall fit for the estimated research model (illustrated in Figure 2) is shown in Table 5. The indices indicated a good fit between the data and the proposed model. The test of hypotheses was based on the direct effects among the constructs as shown in Figure 2 and reported in Table 7. These coefficients were tested at the significance level $p<0.05$, one tailed $(t$-value $=1.65$.

$<$ Take in Figure 2>

Table 7. Summary of statistically significant standardized effects and hypotheses tests

\begin{tabular}{lllllll}
\hline $\begin{array}{l}\text { Independent } \\
\text { variable }\end{array}$ & $\begin{array}{l}\text { Dependent } \\
\text { variable }\end{array}$ & $\begin{array}{l}\text { Std direct } \\
\text { effect }\end{array}$ & $\begin{array}{l}\text { Std } \\
\text { indirect } \\
\text { effect }\end{array}$ & $\begin{array}{l}\text { Std total } \\
\text { effect }\end{array}$ & Hypothesis & Conclusion \\
\hline EDI & ERP & 0.011 & - & 0.011 & H1 & Rejected \\
CAD/CAM & ERP & $0.479^{* *}$ & - & $0.479^{* *}$ & H2 & Supported \\
\hline EDI & QDWM & $0.219^{* *}$ & 0.003 & $0.222^{* *}$ & H3 & Supported \\
ERP & QDWM & $0.269^{* *}$ & - & $0.269^{* *}$ & H4 & Supported \\
CAD/CAM & QDWM & 0.019 & $0.129^{* *}$ & 0.148 & H5 & Rejected \\
\hline EDI & CSR & $0.173^{* *}$ & $0.122^{* *}$ & $0.295^{* *}$ & H6 & Supported \\
ERP & CSR & 0.088 & $0.146^{* *}$ & $0.234^{* *}$ & H7 & Rejected \\
QDWM & CSR & $0.543^{* *}$ & - & $0.543^{* *}$ & H10 & Supported \\
\hline ERP & PPM & 0.098 & $0.174^{* *}$ & $0.272^{* *}$ & H8 & Rejected \\
CAD/CAM & PPM & $0.184^{*}$ & $0.139^{* *}$ & $0.323^{* *}$ & H9 & Supported \\
QDWM & PPM & 0.153 & $0.309^{* *}$ & $0.462^{* *}$ & H11 & Rejected \\
CSR & PPM & $0.569^{* *}$ & - & $0.569^{* *}$ & H12 & Supported \\
\hline PPM & QP & $0.442^{* *}$ & - & $0.442^{* *}$ & H13 & Supported \\
EDI & QP & - & $0.090^{* *}$ & $0.090^{* *}$ & - & - \\
ERP & QP & - & $0.120^{* *}$ & $0.120^{* *}$ & - & - \\
CADM & QP & - & $0.143^{* *}$ & $0.143^{* *}$ & - & - \\
QDWM & QP & - & $0.204^{* *}$ & $0.204^{* *}$ & - & - \\
CSR & QP & - & $0.251^{* *}$ & $0.251^{*}$ & - & - \\
\hline
\end{tabular}

Notes: ${ }^{*} p<0.05 ; * * p<0.01$; (one-tailed); $\mathrm{n}=229$ 


\subsubsection{Direct effects}

According to the results shown in Figure 2, the path coefficient from EDI to ERP was not significant, thus, hypothesis H1 was rejected $(t=0.011 ; p>0.10)$. In contrast, the results provided empirical support for hypothesis H2 ( $t=4.447 ; p<0.01)$, indicating that the adoption of CAD/CAM systems is positively associated with the adoption and use of ERP systems. H3 and H4 were also supported ( $t=2.245 ; p<0.01$ ), thus, EDI and ERP systems directly support QDWM. However, the path between CAD/CAM and QDWM was not significant $(t=0.158 ; p>$ 0.10) leading to the rejection of H5. The results also showed that the path between EDI and CSR was positive and significant $(t=2.231 ; p<0.01)$ but the path from ERP to CSR was not significant $(t=1.111 ; p>0.10)$ suggesting the acceptance of $\mathrm{H} 6$ and rejection of $\mathrm{H} 7(t=1.040 ; p$ $>0.10)$. Similarly, ERP did not have a significant positive direct effect on PPM $(t=1.040 ; p>$ 0.10) but CAD/CAM showed a significant positive direct effect on PPM $(t=1.865 ; p<0.05)$, thus rejecting $\mathrm{H} 8$ and accepting $\mathrm{H} 9$.

H10 was supported $(t=5.308 ; p<0.01)$ thus, QDWM positively contributes to CSR. However, H11 was not supported $(t=1.361 ; p>0.10)$ indicating that QDWM does not directly support PPM. In contrast, H12 and H13 were supported indicating that CSR supports Product and Process Management $(t=4.683 ; p<0.01)$ and that PPM displays a significant effect on Quality Performance $(t=4.668 ; p<0.01)$.

\subsubsection{Indirect effects}

We executed the effects analysis procedure in LISREL in order to examine the indirect and total effects within the model. On the whole, the results indicate that EDI, CAD/CAM and ERP have positive indirect effects on Quality Performance $(t=2.584, p<0.01$; $t=2.772, p<$ 0.01; and $t=2.335, p<0.01$ respectively; Table 7). QDWM and CSR also showed significant indirect positive effects on Quality Performance $(t=2.335, p<0.01$ and $t=2.335, p<0.01$ respectively; Table 7).

Further, to assess the enabling effect of quality management on the relationships between the IT and Quality Performance, two alternative models were estimated. First, the three constructs pertaining to quality management were removed and only the direct effects of EDI, 
ERP and CAD/CAM on Quality Performance were estimated. In this model, the direct effects of IT variables on Quality Performance were not significant at the 0.10 level. Second, the direct effects of EDI, CAD/CAM and ERP on Quality Performance were added to the original model, including the indirect effects, as mediated by quality management. In this specification, none of the direct effects of the IT variables on performance variables was significant at the .10 level with the exception of CAD/CAM showing a standardized significant negative effect on Quality Performance $(t=-2.565 ; p<0.01)$. This result indicates that in organizations with quality management, the adoption of CAD/CAM technology by itself renders a negative effect on Quality Performance, but when integrated into the firm's overall quality management system it renders a positive effect on Quality Performance.

Four of the hypothesized relationships were non-significant. The structural coefficient between CAD/CAM and EDI systems was positive but non-significant. The reason for this result could be due to the widespread use of EDI technology among firms in the sample, that is, firms with high and low levels of ERP use are both using EDI technology intensively. Another nonsignificant relationship was the direct relationship between CAD/CAM and Quality Data and Workforce Management. However, there was a positive indirect effect of CAD/CAM on QDWM through ERP (see Table 7). This result suggests that those firms with a CAD/CAM system integrated with their ERP systems experience a significant positive effect on QDWM.

The results also showed that ERP had a direct positive effect on CSR and PPM but nonsignificant, however the indirect effects of ERP on CSR and PPM were significant. These results might be explained by the use that firms make of their ERP systems. Firms in the sample might be using their ERP systems mainly to collect data and disseminate information across the organization rather than supporting specific areas of the firm such as CSR or PPM for which other specialized IT are better suited (e.g., EDI and CAD/CAM respectively). The only support that CSR and PPM receive from ERP is the role that the ERP plays in as much as collecting the data and providing information necessary for CSR and PPM. Consequently, the effect of ERP on CSR and PPM is mediated by QDWM. A future study could confirm these findings. 
The effect of QDWM on PPM was also in the hypothesized direction but non-significant. This result was unexpected, since QDWM has been shown to have a positive direct effect on PPM. In contrast, the indirect effect of QDWM on PPM was significant suggesting that QDWM contributes to PPM through CSR.

\section{Discussion and practical implications}

The findings of this study add to literature analyzing the factors that affect the relationship between IT and performance. Specifically, it adds to recent literature related to the contingency factors in the relationship between IT and quality performance (Lee et al., 2010), by identifying quality management as an effective mediator in the relationship. Therefore, the emphasis on technology alone cannot singularly ensure high performance but it is the fusion of people, business, and technology resources, with the "management difference” (i.e., quality management) producing the critical distinctive advantage.

Also the results of this investigation add to previous literature focused on the role of IT to support quality management (Ang et al., 2001; Sánchez-Rodríguez et al., 2006). Previous studies only referred to the impact of IT on quality management in general terms but did not consider specific examples of IT, neither showed the link between these IT and their related quality management dimensions. As such, the results of our study showed that EDI directly supports Customer and Supplier Relations, ERP directly supports Quality Data and Workforce Management, and CAD/CAM directly supports Product and Process Management. Also important was the indirect role played by EDI and CAD/CAM in Quality Data and Workforce Management. These findings supports the view that IT in a quality management system act as a means to get rapid and more accurate information and as a feedback mechanism for the purposes of continuous improvement (Chang, 2006). In addition, this role of IT in quality management has pervasive associated benefits, affecting the attitude to organizational life for all employees, and promoting employee empowerment, teamwork, motivation, training and general industrial relations (Cua et al., 2001).

Our research also adds to research on ERP systems and quality management (Laframboise and Reyes, 2005; Forslund, 2010; Dezdar and Sulaiman, 2009) and confirm the 
complementarity between ERP and quality management. Previous literature has argued that TQM is an appropriate antecessor of ERP adoption (McAdam and Galloway, 2005; Li et al., 2008) since TQM emphasizes customer satisfaction, top management involvement, and life-long learning, all of which are building blocks of implementing enterprise information technology. However, ERP could also be proposed as a predecessor of quality management (Li et al., 2008). The findings of our study provide evidence in this direction suggesting that ERP adoption can impact quality management. Specifically, the results showed that ERP directly support Quality Data and Workforce Management, and indirectly Customer and Supplier Relations and Product and Process Management (see Table 4.) Thus, ERP systems provide quality management programs not only with an effective tool to collect and disseminate quality data and information and supporting staff empowerment, but also with a way to facilitate closer collaborative relationships with customers and suppliers, and enable a cross-functional approach to their product design and process control activities.

In addition, the results of our study provide evidence that the integration between ERP and quality management delivers results on quality performance. Conceptually, previous studies had argued that implementing both ERP and TQM would achieve predominant success (Schniederjans and Kim, 2003) and that ERP implementation positively affects a firm's performance when the enterprise information system implementation directly interacts with quality improvement systems (Laframboise and Reyes, 2005). However, there was little empirical evidence. The findings of our study confirm that ERP has a positive indirect effect on quality performance mediated by quality management.

The results also add to literature on the effect of TQM on performance (Kumar and Antony, 2008; Sit et al., 2009) and are in line with findings of recent research (Kaynak and Hartley, 2008) indicating that Quality Data and Workforce Management and Customer and Supplier Relations do not have a direct effect on performance but their effect is through Product and Process Management. This finding does not mean that improvements in other quality management areas are irrelevant to quality performance but on the contrary, they positively contribute to quality performance indirectly through Product and Process Management. As such, improvements in Quality Data and Workforce Management are carried through Customer and 
Supplier Relations that pass onto Product and Process Management to finally impact Quality Performance. Thus, these results confirm that establishing an effective system for accumulating and disseminating data regarding customers' requirements and feedback throughout the organization is crucial to improving product design and process management and, ultimately, performance (Kaynak and Hartley, 2008).

The findings of this research also offer some support to the literature on the role of quality management in knowledge creation (Linderman et al., 2004; Tan et al., 2003; Moreno et al., 2005)\}. From a resourced-based view perspective, knowledge creation can be seen as part of the process to develop organizational resources and capabilities that are difficult to imitate by competitors. In this context, Information technology has a key role to play in this knowledge creation process as a key facilitator of organizational memory and the ability to capture and integrate explicit knowledge by making it easy to codify, communicate, assimilate, store, and retrieve. Although this study does not measure the extent of knowledge creation in quality management, it shows how IT, a supporting factor of this knowledge creation, has a positive effect on quality management and quality performance. Therefore, within the limitations of this study, we could argue that IT allows organizations with quality management programs to be able to better manage their quality related knowledge, and that this relationship produces results on quality performance.

The results of this study have also practical implications for managers. The results of this study can serve as evidence to management in firms with quality management programs that investment in information technology pays off in increased quality performance when integrated with quality management efforts. Consequently, new investments in information technology should be aligned with quality management and a cross-functional approach to IT selection where the voice of quality management is represented might be advisable. In addition, firms that are initiating the implementation of a quality management program or interested in advancing their existing one could do so by investing in new IT along the guidelines discussed here.

There are also implications for firms with no quality management programs. The results provide evidence that IT and quality management are complementary resources and 
consequently firms looking into obtaining further results from their investments in IT could do so by adopting quality management practices. For example, a firm with CAD/CAM technology could further improve quality performance by relating this technology with process design (e.g., Taguchi methods) and process control tools (e.g., statistical process control).

\section{Conclusions}

The main objective of this paper was to deepen our understanding of the relationship between information technologies, quality management capabilities and quality performance. Using the resource-based view of the firm and data collected from 219 manufacturing firms we found that quality management capabilities (Customer and Supplier Relations, Product and Process Management, Quality Data and Workforce Management) can help realize the benefits of information technology (EDI, CAD/CAM and ERP) and gain performance advantages. Therefore, the results of this study support the argument that IT and quality management are complementary resources and that the emphasis on technology alone cannot singularly ensure high performance. It is the fusion of people, business, and technology resources, with the “management difference” (i.e., quality management) producing the critical distinctive advantage.

From a theoretical point of view this research has provided evidence that supports the existence of a positive effect of IT on quality performance. Nonetheless, the results suggest that this effect is produced as long as these IT are used to better implement or support a series of quality management capabilities. The fact that IT was related to quality management and quality performance indicates that investment in IT should be taken into consideration in the literature about quality management as a facilitator and in the IT literature as a mediator on performance.

At this point, it is important to acknowledge important limitations of our study that might provide opportunities for future research. Though the constructs developed in this study exhibit acceptable reliability for the purposes at hand, future research should refine them and consider adding new indicators. Also, inferences in this study are based on cross-sectional data which make causal claims difficult; a longitudinal study could help solve this problem. The study framework was tested primarily with a single informant from each organization. A dataset with multiple informants from each organization can enhance the validity of the findings. This study 
used perceived measures of quality performance by managers. Future work can attempt to blend objective data in an effort to validate the findings. Also the data was collected in 2001 and the picture of the use of IT and quality management in firms is likely to have changed since the collection of the data. Despite these limitations, this study paves the way for researchers and managers to more fully capitalize on the potential of the integration between information technology and quality management to foster a firm's quality performance and competitive position.

\section{References}

Ahire, S., Golhar, D. and Waller, M. (1996), "Development and validation of TQM implementation constructs", Decision Sciences, Vol. 27 No. 1, pp. 23-56.

Ang, C., Davies, M. and Finlay, P. (2001), "An empirical study of the use of information technology to support total quality management", Total Quality Management, Vol. 12 No. 2, pp. 145-157.

Bagozzi, R. and Yi, Y. (1988), "On the evaluation of structural equation models", Academy of Marketing Science, Vol. 6 No. 1, pp. 74-93.

Barney, J. (1991), "Firm resources and sustained competitive advantage", Journal of Management, Vol. 17 No. 1, pp. 99-120.

Barney, J. (1986), "Strategic factor markets: Expectation, luck, and business strategy", Management Science, Vol. 32 No. 10, pp. 1231-1241.

Brah, S.A. and Lim, H.Y. (2006), "The effects of technology and TQM on the performance of logistics companies", International Journal of Physical Distribution \& Logistics Management, Vol. 36 No. 3, pp. 192-209.

Byrne, B.M. (2001), Structural equation modeling with AMOS: Basic concept, applications, and programming, Lawrence Erlbaum Associates, Mahwah, NJ.

Cagliano, R. and Spina, G. (2000), "Advanced manufacturing technologies and strategically flexible production", Journal of Operations Management, Vol. 18 No. 2, pp. 169-190.

Chang, H.H. (2006), "An empirical evaluation of performance measurement systems for total quality management", Total Quality Management \& Business Excellence, Vol. 17 No. 8, pp. 1093-1109.

Chau, P. (1997), "Reexamining a model for evaluating information center success using a structural equation modelling approach", Decision Sciences, Vol. 28 No. 2, pp. 309-334.

Cua, K.O., McKone, K.E. and Schroeder, R.G. (2001), "Relationships between implementation of TQM, JIT, and TPM and manufacturing performance", Journal of Operations Management, Vol. 19 No. 6, pp. 675-694.

Czajkiewicz, Z.J. and Wielicki, T.R. (1994), "CIM - A journey to manufacturing excellence", Computers \& Industrial Engineering, Vol. 27 No. 1-4, pp. 91-94.

Das, A., Handfield, R.B., Calantone, R.J. and Ghosh, S. (2000), "A contingent view of quality management - the impact of international competition on quality", Decision Sciences, Vol. 31 No. 3, pp. 649-690. 
Dean, J. and Bowen, D. (1994), "Management theory and total quality: Improving research and practice through theory development", Academy of Management Review, Vol. 19 No. 3, pp. 392-418.

Dewhurst, F.W., Martinez-Lorente, A.R. and Sánchez-Rodríguez, C. (2003), "An initial assessment of the influence of IT on TQM: A multiple case study", International Journal of Operations and Production Management, Vol. 23 No. 4, pp. 348-374.

Dezdar, S. and Sulaiman, A. (2009), "Successful enterprise resource planning implementation: Taxonomy of critical factors", Industrial Management \& Data Systems, Vol. 109 No. 8, pp. 1037-1062.

Dillman, D. (1978), Mail and telephone surveys: The total design method, John Wiley, New York.

Dion, P. (2008), "Interpreting structural equation modeling results: A reply to Martin and Cullen", Journal of Business Ethics, Vol. 83 No. 3, pp. 365-368.

Dow, D., Samson, D. and Ford, S. (1999), "Exploding the myth: Do all quality management practices contribute to superior quality performance?", Production and Operations Management, Vol. 8 No. 1, pp. 1-27.

Dunk, A.S. (2002), "Product quality, environmental accounting and quality performance", Accounting, Auditing \& Accountability Journal, Vol. 15 No. 5, pp. 719.

Flynn, B., Sakakibara, S. and Schroeder, R. (1994), "A framework for quality management research and an associated measurement instrument", Journal of Operations Management, Vol. 11 No. 4, pp. 339-366.

Fok, L.Y., Fok, W.M. and Hartman, S.J. (2001), "Exploring the relationship between total quality management and information system development", Information \& Management, Vol. 38 No. 6, pp. 355-371.

Forslund, H. (2010), "ERP systems' capabilities for supply chain performance management", Industrial Management \& Data Systems, Vol. 110 No. 3, pp. 351-367.

Forza, C. (1995), "The impact of information systems on quality performance: An empirical study", Journal of Operations and Production Management, Vol. 15 No. 6, pp. 69-83.

Foster, S.T. and Ogden, J. (2008), "On differences in how operations and supply chain managers approach quality management", International Journal of Production Research, Vol. 46 No. 24, pp. 6945-6961.

Frohlich, M.T. and Dixon, J.R. (2001), "A taxonomy of manufacturing strategies revisited", Journal of Operations Management, Vol. 5 No. 19, pp. 541-558.

Fynes, B. and De Burca, S. (2005), "The effects of design quality on quality performance", International Journal of Production Economics, Vol. 96 No. 1, pp. 1-14.

Garver, M.S. and Mentzer, J.T. (1999), "Logistics research methods: Employing structural equation modeling to test for construct validity", Journal of Business Logistics, Vol. 20 No. 1, pp. 33-57.

Gunasekaran, A. and Ngai, E.W.T. (2004), "Information systems in supply chain integration and management", European Journal of Operational Research, Vol. 159 No. 2, pp. 269-295.

Gupta, M. and Kohli, A. (2006), "Enterprise resource planning systems and its implications for operations function", Technovation, Vol. 26 No. 5, pp. 687-696.

Gutiérrez, L.J.G. and Pérez, V.F. (2010), "Managerial networks and strategic flexibility: A QM perspective", Industrial Management \& Data Systems, Vol. 110 No. 8, pp. 1192.

Hair, J., Anderson, R., Tatham, R. and Black, W. (1995), Multivariate data analysis with readings, Prentice Hall, Englewood Cliffs, NJ. 
Jiang, B.C. and Chiu, S.-. (2002), "Form tolerance-based measurement points determination with CMM", Journal of Intelligent Manufacturing, Vol. 13 No. 2, pp. 101-108.

Johnson, P.F., Klassen, R.D., Leenders, M.R. and Awaysheh, A. (2007), "Utilizing e-business technologies in supply chains: The impact of firm characteristics and teams", Journal of Operations Management, Vol. 25 No. 6, pp. 1255-1274.

Jöreskog, K., Sörbom, D., du Toit, S. and du Toit, M. (2000), LISREL 8: New statistical features, Scientific Software International, Lincolnwood, IL.

Jung, J.Y., Wang, Y.J. and Wu, S. (2009), "Competitive strategy, TQM practice, and continuous improvement of international project management", The International Journal of Quality \& Reliability Management, Vol. 26 No. 2, pp. 164-183.

Kaynak, H. and Hartley, J.L. (2008), "A replication and extension of quality management into the supply chain", Journal of Operations Management, Vol. 26 No. 4, pp. 468-489.

Kock, N.F.J. and McQueen, R.J. (1997), "Using groupware in quality management programs", Information Systems Management, Vol. 14 No. 2, pp. 56-62.

Kumar, M. and Antony, J. (2008), "Comparing the quality management practices in UK SMEs", Industrial Management \& Data Systems, Vol. 108 No. 9, pp. 1153-1166.

Laframboise, K. and Reyes, F. (2005), "Gaining competitive advantage from integrating enterprise resource planning and total quality management", Journal of Supply Chain Management, Vol. 41 No. 3, pp. 49-64.

Lee, C., Huang, S., Barnes, F. and Kao, L. (2010), "Business performance and customer relationship management: The effect of IT, organisational contingency and business process on taiwanese manufacturers", Total Quality Management \& Business Excellence, Vol. 21 No. 1, pp. 43-65.

Li, L., Markowski, C., Xu, L. and Markowski, E. (2008), "TQM - A predecessor of ERP implementation", International Journal of Production Economics, Vol. 115 No. 2, pp. 569580.

Li, L., Su, Q. and Chen, X. (2011), "Ensuring supply chain quality performance through applying the SCOR model", International Journal of Production Research, Vol. 49 No. 1, pp. 33-57.

Linderman, K., Schroeder, R., Zaheer, S., Liedtke, C. and Choo, A.S. (2004), "Integrating quality management practices with knowledge creation processes", Journal of Operations Management, Vol. 22 No. 6, pp. 589-607.

Lo, V.H.Y., Yeung, A.H.W. and Yeung, A.C.L. (2007), "How supply quality management improves an organization's quality performance: A study of Chinese manufacturing firms", International Journal of Production Research, Vol. 45 No. 10, pp. 2219-2243.

Madu, C.N. (2005), "Strategic value of reliability and maintainability management", The International Journal of Quality \& Reliability Management, Vol. 22 No. 3, pp. 317-329.

Martinez-Lorente, A.R., Sanchez-Rodriguez, C. and Dewhurst, F.W. (2004), "The effect of information technolgies on TQM: An initial analysis", International Journal of Production Economics, Vol. 89 No. 1, pp. 77-93.

McAdam, R. and Galloway, A. (2005), "Enterprise resource planning and organisational innovation: A management perspective", Industrial Management \& Data Systems, Vol. 105 No. 3, pp. 280-291.

McAdam, R. and Henderson, J. (2004), "Influencing the future of TQM: Internal and external driving factors", The International Journal of Quality \& Reliability Management, Vol. 21 No. 1, pp. 51-72. 
McQuitty, S. (2004), "Statistical power and structural equation models in business research", Journal of Business Research, Vol. 57 No. 2, pp. 175-183.

Melville, N., Kraemer, K. and Gurbaxani, V. (2004), "Review: Information technology and organizational performance: An integrative model of it business Value1", MIS Quarterly, Vol. 28 No. 2, pp. 283-322.

Mjema, E.A.M., Victor, M.A.M. and Mwinuka, M.S.M. (2005), "Analysis of roles of IT on quality management", The TQM Magazine, Vol. 17 No. 4, pp. 364-375.

Montaldo, E., Sacile, R. and Boccalatte, A. (2003), "Enhancing workflow management in the manufacturing information system of a small-medium enterprise: An agent-based approach", Information Systems Frontiers, Vol. 5 No. 2, pp. 195-205.

Moreno, A.R., Morales, V.G. and Montes, F.J.L. (2005), "Learning during the quality management process: Antecedents and effects in service firms", Industrial Management \& Data Systems, Vol. 105 No. 8, pp. 1001-1022.

Overby, J.W. and Min, S. (2001), "International supply chain management in an internet environment", International Marketing Review, Vol. 18 No. 4, pp. 392-420.

Peteraf, M.A. (1993), "The cornerstones of competitive advantage: A resource-based view", Strategic Management Journal, Vol. 14 No. 3, pp. 179-192.

Powell, T.C. and Dent-Micalef, A. (1997), "Information technology as competitive advantage: The role of human, business, and technology resources", Strategic Management Journal, Vol. 18 No. 5, pp. 375-405.

Sánchez-Rodríguez, C., Dewhurst, F.W. and Martínez-Lorente, A.R. (2006), "IT use in supporting TQM initiatives: An empirical investigation", International Journal of Operations \& Production Management, Vol. 26 No. 5, pp. 486-504.

Sandelands, E. (1994), "Du pont's integrated vision", International Journal of Physical Distribution \& Logistics Management, Vol. 24 No. 3, pp. 31-33.

Saraph, J., Benson, P. and Schroeder, R. (1989), "An instrument for measuring the critical factors of quality management", Decision Sciences, Vol. 20 No. 4, pp. 810-829.

Schniederjans, M.J. and Kim, G.C. (2003), "Implementing enterprise resource planning systems with total quality control and business process reengineering: Survey results", International Journal of Operations \& Production Management, Vol. 23 No. 3/4, pp. 418-430.

Sila, I. and Ebrahimpour, M. (2005), "Critical linkages among TQM factors and business results", International Journal of Operations \& Production Management, Vol. 25 No. 11, pp. 1123-1156.

Sila, I. (2007), "Examining the effects of contextual factors on TQM and performance through the lens of organizational theories: An empirical study", Journal of Operations Management, Vol. 25 No. 1, pp. 83-109.

Sit, W., Ooi, K., Lin, B. and Chong, A.Y. (2009), "TQM and customer satisfaction in malaysia's service sector", Industrial Management \& Data Systems, Vol. 109 No. 7, pp. 957-975.

Soliman, F., Clegg, S. and Tantoush, T. (2001), "Critical success factors for integration of CAD/CAM systems with ERP systems", International Journal of Operations \& Production Management, Vol. 21 No. 5/6, pp. 609-629.

Soltani, E., Azadegan, A., Liao, Y. and Phillips, P. (2011), "Quality performance in a global supply chain: Finding out the weak link", International Journal of Production Research, Vol. 49 No. 1, pp. 269-293. 
Tan, B., Lin, C. and Hung, H. (2003), "An ISO 9001: 2000 quality information system in ecommerce environment", Industrial Management \& Data Systems, Vol. 103 No. 8/9, pp. 666-676.

Themistocleous, M., Irani, Z. and O'Keefe, R.M. (2001), "ERP and application integration", Business Process Management Journal, Vol. 7 No. 3, pp. 195-204.

\section{Appendix}

Survey indicators

INFORMATION TECHNOLOGIES

To what extent does your company use the following IT? (1-no use at all to 5- intensive use)

edi1 Electronic data interchange (EDI) with customers/clients

edi2 Electronic data interchange (EDI) with suppliers

erp1 Manufacturing Requirements Planning (MRP)

erp2 Enterprise Resource Planning (ERP) for example SAP

cadm1 Computer Aided Design (CAD)

cadm2 Computer Aided Manufacturing (CAM)

\section{QUALITY MANAGEMENT}

To what extent does your company use quality management in the following : ( 1 for no use at all and 5 for intensive use)

qdwm1 Information analysis

qdwm2 Workforce management

csr1 Customer relationships

csr2 Supplier relationships

ppm1 Product design

ppm2 Process flow management

\section{QUALITY PERFORMANCE}

Please indicate how do the following measures at your plant compare to industry competition?:

(1 no competitive and 5 highly competitive)

qp1 Rate of defective units

To what extent do you agree with the following statements?: (1 totally disagree and 5 totally agree)

qp2 The quality of our products is superior to that of our competitors

qp3 The quality performance in our plants in the last 3 years has been low compared to that of firms in our industry (reverse coded) 